\title{
Application of themes from Al-Mawwaq's work in reforming the Deoband curriculum in Islamic education in the South African Darul Ulooms
}

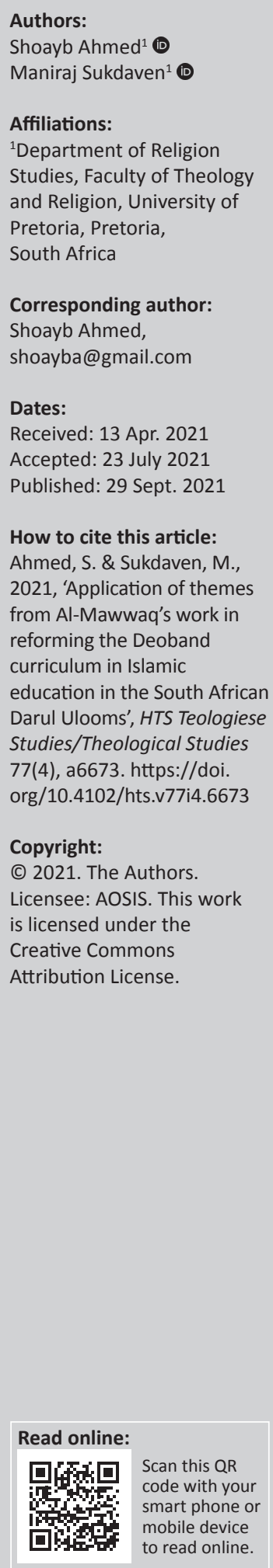

Historically, most Darul Ulooms in South Africa have been modelled along the curriculum of Darul Uloom Deoband in India, which was established in 1866, and there is a need for reforming the curriculum in a world that has evolved over time. In recent years, the role of the Darul Uloom has become more crucial as more students, both nationally and internationally, are now studying at the South African Darul Ulooms. This research article aims to propose some reforms to the current Deoband curriculum adopted by some of these South African Darul Ulooms.

Contribution: This proposal suggests applying themes from Al-Mawwaq's work to foster reforms to the curriculum, which will enhance and produce scholars who are more tolerant and able to deal with the changing circumstances, both nationally and internationally.

Keywords: Spain; Mauritania; curriculum; education; Darul Uloom; South Africa.

\section{Introduction}

Wherever Islam spread, scholars accompanied the different delegations. As Islam spread to Africa, it also spread, in particular, into the desert of Mauritania (Hiskett 1984:244-251).

This research article traces the educational establishments and developments particularly in Spain and Mauritania, and thereafter, attempts to use the lessons from these two regions to reform and enhance Islamic education in the Darul Ulooms in South Africa. The selection of Spain is because of the works of a Spanish Muslim scholar, Al-Mawwaq, and the themes deduced from his work, which are used as suggested reforms to the curriculum adopted by South African Darul Ulooms.

While Mauritania has been selected not merely because a manuscript of Al-Mawwaq's book is preserved in Mauritania but also because his book is held in high regard and relied upon by leading Mauritanian scholars, along with the academic excellence and literary legacy of the Mauritanian scholars.

\section{The mahdarah and the written legacy amongst the Mauritanians}

Mauritania is significant in the scholarly links between Muslims from Africa and Europe. Scholars travelled and met other scholars and those who did not travel, their books reached many different areas. Al-Mawwaq's book is one of the examples because he did not leave Granada in Spain; however, a copy of his book was preserved in Mauritania inside a private collection.

More significant is that the Mauritanian educational system, known as the mahdarah, has proven to be very effective, particularly in developing an advanced level of expertise in the Arabic language and its poetry, and a mastery of the Maliki School. This system relies greatly on memorisation and can be useful in the South African Darul Ulooms and can help to enhance the standard of Arabic language and the level of proficiency amongst the students.

The Mauritanians embraced the faith and the language and eventually developed their own unique educational institution that suited their Bedouin lifestyle. The mahdarah was established in 1039 with the arrival of the scholar, Abdullah ibn Yasin al-Jazuli (d. 1057) (Wald Maqam 2014:2-3). The academic revival and resurgence in Mauritania are attributed to Muslims who fled Spain after the fall of Granada in 1492 (Lovejoy 2009:219). 
The mahdarah plays a significant role in eradicating illiteracy, and its relevance depends on how it embraces new teaching methods with minor changes to its curriculum.

The Mauritanian scholars authored many books, and the study of the Islamic Sciences flourished during the 17th century (Wald Mayarah 2013:2). Scholars suggest that Andalus influenced Mauritanian education, and that the emigration of Muslims from Spain to Western Sudan and the Sahara began before the fall of Granada in 1492 (Lovejoy 2009:222)

Attempts to document and codify the manuscripts in Mauritania date back to 1934 when two female scholars visited the Siddiya Library in Boutilimit, where they saw two large rooms filled with wooden chests that contained hundreds of books (Kratli 2004:12). Between 1979 and 1997, Rainer Oswald, Ulrich Rebstock and Tobias Mayer photographed over 2500 manuscripts or 134000 pages of text from more than 200 private libraries in Mauritania (Bruckner \& Kandzin 2001:401-405).

There were strong cultural and scholarly links between Cordoba, Fez and the Sahara. The Mauritanians relied on some didactic poems and books that were authored by Moroccan and Spanish Muslim scholars. The books of Ibn Rushd, the Andalusian philosopher, were used in teaching Islamic Jurisprudence of the Maliki School (Saalim 2004:2). Books authored by Andalusian scholars spread to other parts of the world. The book, Sanan al-Muhtadin fi Maqamat al-Din, by Al-Mawwaq, which was authored in the later part of the author's life at around 1480, is one of the examples. This book is important because its related themes will be used in the educational reform of the Darul Ulooms in South Africa.

\section{Al-Mawwaq}

Al-Mawwaq lived in Granada, Spain, and through his biography, it has been established that he did not leave the city and eventually died there in 1492. According to Al-Zirikli (1998:51), he died in the very year the city fell to the Christians. Muhammad ibn Yusuf ibn Abi al-Qasim al-Abdari, Abu Abdullah, Al-Mawwaq was a scholar and juris-consult (mufti) and authored many books in Islamic Jurisprudence according to the Maliki School and Sufism.

The selection of Al-Mawwaq is important because he is a classical Muslim scholar who's knowledge and application thereof blended figh, maqasid and Sufism. Al-Mawwaq lived in an environment that resembled that of the Muslims in South Africa. The Muslims in South Africa are a minority, and interact and coexist with the broader community who are adherents to other faiths. Similarly, Al-Mawwaq who served as the mufti of Granada interacted with the Muslims and adherents of other faiths and also pronounced a fatwa on whether the Muslims should continue to live under the Christians or instead migrate (Miller 2000:256-288). The lessons from the Spanish Muslim society and scholars, such as Al-Mawwaq, could inspire us in South Africa and other minorities to work towards creating a society of tolerance and understanding. The selection of Al-Mawwaq, being a Maliki scholar, is not a problem for the Darul Ulooms in South Africa who are predominantly adherents to the Hanafi School because there is a strong historical and academic link between the schools of Islamic jurisprudence (figh). Muhammad ibn al-Hasan al-Shaybani (d. 805) who was one of the foremost students of Imam Abu Hanifah studied under Imam Malik and is one of the most authoritative narrators of the book by Imam Malik titled, al-Muwatta, which was authored in 775. A more recent Deobandi scholar who is revered amongst South African Deobandis is Muhammad Zakariya Khandehlawi (d. 1982), who authored a voluminous commentary to al-Muwatta that was very well received by scholars across the world (al-Kawthari 1968:62, 81). The Muwatta is regarded as one of the earliest compilations of Hadith and is taught in the final year of all major Darul Ulooms in South Africa. The works of famous Egyptian scholars of the Shafi'i school continue to be taught in the Darul Ulooms. These include the books, such as Tafsir alJalalayn by Al-Suyuti (d. 1505) and Al-Mahalli (d. 1460) and Nukhbat al-Fikr by Ibn Hajr (d. 1449).

\section{Islam and Islamic education in South Africa}

Before proposing any reforms, it is essential that Islam and Islamic education is understood within its context. Unlike Spain and North Africa, Islam in South Africa is recent. The first Muslims arrived as political prisoners in 1658 and not as conquerors. Shaykh Yusuf (d. 1699) of Macassar is regarded as the first Muslim scholar and a person who resisted the Dutch; however, most importantly, he was Ash'ari in doctrine, Shafi'i in the school of jurisprudence and an adherent to the Sufi way. He taught the slaves of the Cape at a time when the practice of Islam was prohibited (Da Costa \& Davids 1994:23).

Other educational milestones in the history of Islam in South Africa include the establishment of the first mosque and madrasa by Tuan Guru (d. 1807) in Dorp Street, Cape Town, which served as a school to teach theology and a school by the Turkish scholar, Shaykh Abu Bakr Effendi who arrived in 1860 (Da Costa \& Davids 1994:23).

Although there were some Muslims of Indian origin who were amongst the early arrivals in the Cape, the formal arrival of the Indians to the coast of Natal took place under the British. They arrived in 1860 as indentured labourers. These Indian Muslims were unified in Islamic doctrine and the majority adhered to the Hanafi school, although there were adherents to the Shafi'i school. The Sufi approach and practices were common amongst them (Shaikh 1994:8). The Deobandi-Barelwi divide is something that originated in India and is a course of debate despite the former aspects that unite them.

Numerous other schools and madrasas were established. Arabic and Islamic studies were introduced at some South African Universities. The first Darul Uloom in the country 
was established in Newcastle in 1973 (Sayed 2010:5; Tayob et al. 2011:43). Subsequently, other Darul Ulooms have been established, including the Islamic Peace College of South Africa, with the latter offering an accredited undergraduate programme (Sayed 2010:56). This article aims to suggest reforms to the Darul Uloom curriculum without discussing the Deobandi-Barelwi or even Shia differences, because the Darul Ulooms that follow the Deoband curriculum are the most visible in the South African Muslim community. Their impact is more apparent than any other. In fact, the Darul Ulooms that exist in the Cape have been established by graduates from the institutions in Newcastle, Azaadville and Lenasia - Zakariya, which are all Deobandi institutions. In addition, the curriculum of the Barelwi Darul Ulooms is very similar.

The Darul Ulooms play a vital and significant role in the country. They helped to preserve Islam and its teachings within the community by producing home-grown scholars (ulama) who serve as imams and teachers of Islamic studies across the country and more recently even abroad.

The need to reform the curriculum in the South African Darul Ulooms:

The scholars (ulama) have been negatively targeted in the last two centuries and have been blamed for a plethora of social and intellectual ills, the failure to solve ; worldly problems' and the alleged failure to adapt to situations (Ingram 2018:144). The world is changing at a rapid pace, and the scholars have to provide solutions and guidelines to the Muslim community on a range of matters ranging from crypt-currencies, modern developments in medicine and the recent coronavirus and the challenges it presented with regard to the closure of places of worship and adapting certain aspects of the prayer and the permissibility of the vaccines. There is a need to reform or to adapt teaching methodology, pedagogy, governance and financial management of these institutions. The suggestion for reform in the Darul Uloom is not something new. Proponents of reform include a Deoband trained scholar, Ubaydullah Sindi (d. 1944), and another scholar, Shibli Nomani (d. 1914), called for reforms in India, and a South African born academic and Darul Uloom graduate, Ebrahim Moosa and an Indian Deoband graduate, Waris Mazhari, have also made similar calls. (Moosa 2015:152, 242; www.warismazhari.blogspot.com)

The failure or reluctance of the Darul Uloom to improve the curriculum is motivated by the fact that the Darul Uloom is seen as the custodian of authentic Islamic education and not necessarily opposed to modernity. Standards are not achieved because of the lack of adequate experts in various disciplines. Therefore, modernisation is the recovery of the authentic holistic understanding of knowledge so the scholars can reclaim their role as spokespersons for Islam. The Nizami curriculum is a product of a specific society and understanding suited to the particular social and administrative needs of the times (Noor, Sikand \& Bruinessen 2008:21-45).

In recent years, the role of the Darul Uloom has become more crucial. Previously, many South Africans travelled to the Middle East to pursue Islamic studies. Recent political events have negatively impacted on the numbers of students travelling abroad and the foreigners arriving in the country to study Islam have increased. Some graduates from the Darul Uloom in Newcastle have established similar institutions in Cape Town, while Mufti Taha Karan (d. 2021) who graduated from Deoband established an institution in the Cape dedicated to teaching the Shafi'i school. Thus, the Darul Ulooms need to reform accordingly so that the graduates can make more meaningful contributions to their communities and be positive agents of coexistence in a South African society that is very different from India.

The rationale for reform is because of the direct implication on Islamic education in SA, the nature of Muslim leadership and subsequently its impact on the community. As a result of the links South African Darul Ulooms have with other countries because of its graduates, reforms in the curriculum have an even broader relevance.

We know that the syllabus in the Indian madrasas went through a process of gradual transformation over time, corresponding with the changing needs of the state (Sikand 2008:120). Hence, transformation needs to continue in a rapidly changing society. There have been calls for reform in the past and in the present. These have come from both Darul Uloom graduates and university graduates. The scholars who established the Darul Uloom in Deoband modified the Nizami curriculum by reducing the number of books on philosophy and logic and by increasing the number of texts on hadith, figh and tafsir (Ingram 2018:88, 107; Sikand 2008:124). One of the earliest Deobandi scholars, Muhammad Qasim (d. 1880), felt that students should study the 'new philosophy' of the West and not the one derived from the Greeks (Metcalf 1978:118).

The ulama are not confined to the mosque or the madrasah but rather they play an important role as leaders in the community and in social reform. The present curriculum has remained largely stagnant over the last three centuries with minor modifications. The reforms to the curriculum will ensure that the scholars are not cut-off from the fast-changing world, which at times makes it seem like they suffer from an inferiority complex. The reforms will produce more accomplished scholars that will also address the problem of employment, it will also promote a harmonious relationship between the ulama and the specialists of the worldly sciences, and it will assist in propagating Islam and assist them in refuting new ideologies. In addition, it will expose them to the literature outside the syllabus. Furthermore, it will provide a holistic broad-based understanding so that the graduates are not radicalised (Sikand 2008:128-143).

The Darul Uloom specialises in teaching classical Islamic theology and legal texts, commentaries on the Quran, with emphasis on studying the Prophet's life and complex details on how to navigate public and private norms. Secondary disciplines, such as Arabic and logic, are also taught. Madrasas advocate the public understanding of morality, 
ethics and conduct, which has impacted on family matters, finance and politics. Madrasas also support and maintain the practices of rituals, prayer and the remembrance of God (Moosa 2015:13-22). There is a perception that the Darul Ulooms are opposed to modern sciences, and therefore, these are not taught. Al-Mawwaq and Al-Ghazali are scholars who advocated that the study of the other sciences, in order for the society to function optimally, is a communal obligation (Al-Mawwaq 2002:167, 266).

Historically, most Darul Ulooms in South Africa have been modelled along the curriculum of Darul Uloom Deoband in India, which was established in 1866. The curriculum is based on the Nizami system, which was established in the 18th century (Rizvi 1980:49). There are Darul Ulooms in other South Asian countries, such as Pakistan and Afghanistan. In Pakistan, the Darul Uloom ideology is divided into five categories, namely, The Deobandi, the Barelwi, the Ahl al-Hadith, the Shia and the Jamat Islami (ed. Vestenskov 2018:22).

Initially, the Nizami curriculum had only one major Hadith work, and it concentrated on the rational sciences, although the scholars did not regard the rational and Islamic Sciences as rivals. In the Nizami curriculum, the text was selected for its pedagogical merits commensurate with the development of the student (Moosa 2015:88). Eventually, the scholars and founders of the Darul Uloom in Deoband adjusted the curriculum with regard to the duration of study and its content. They reduced the number of rational subjects and introduced a more intense study of Hadith (Ingram 2018:88, 107).

Deobandi thought may be summarised as mainstream Sunni, which manifested itself in Maturidi theology, the Hanafi School of Islamic Jurisprudence and Sufism that included the Chisti, Naqshandi, Suhrawardi and Qadiri Orders. The practical application of this was an extension of the legacy of Shah Waliullah (d. 1762) as per the teachings of its founders Qasim Nanotwi (d. 1880) and Rashid Ahmad Gangohi (d. 1905) (Rizvi 1980:108, 325).

The affiliation of South African Muslims to the Darul Uloom dates back to the arrival of the Indian Muslims to the country in 1860 (Shaikh 1994:8). Many of those early Muslims were connected in some way to Deoband. Qasimi cited a scholar known as Ahmad Buzurg Surti (d. 1951) who graduated from Deoband in 1903 and gave the pledge of fealty to Rashid Ahmad Gangohi (d. 1905) and spent time in South Africa before finally returning to India. He also mentions the generous financial contributions made by South African Indian Muslims to Deoband as early as 1910 (Qasimi 2016:7-8). This is an indication of the early connection between the Indian Muslims and Deoband. In fact, Ingram mentioned that outside of India, the largest concentration of adherents to the Deoband methodology is South Africa (Ingram 2011:11-12). Deoband methodology gained prominence through the Islamic missionary work that was and continues to be carried out by the Tablighi movement. This movement was established in India by Muhammad
Ilyas (d. 1944) who studied under some of the founders of Darul Uloom Deoband. This movement reached South Africa in the 1960s. The written work of prominent Deobandi scholars, such as Muhammad Zakariya Khandelwi (d. 1982), promoted Deobandi thought along with visits to South Africa by senior Deoband scholars (Ingram 2018:19; Reetz 2016:88).

The Darul Ulooms in Lenasia and Azaadville are the most prominent and well-established Deobandi institutions in South Africa (Qasimi 2016:9-10). Many institutions have adhered to the Nizami curriculum with some adaptation. One adjustment of note is the exclusion of the teaching of Gujerati.

\section{Some general suggestions for reform in the Darul Ulooms}

Prior to discussing the themes in Al-Mawwaq's book, a few general suggestions will be presented. These are not restricted to the curriculum but rather incorporate various aspects that are administrational.

In 1994, supporters of the Darul Uloom decided not to reform the curriculum, although Qari Tayyib, who was a rector at Darul Uloom Deoband, argued that there was room for reformation (Noor et al. 2008:36). These reforms would include a revision of the texts that would include theology of the past and present, and address contemporary developments related to Figh, particularly with regard to Islamic finance and medicine. This will enable better synergy between the Muslim scholar and the modern educated Muslim.

Teaching methods need to be broadened by encouraging students to read beyond the scope of the prescribed syllabus along with added debate, discussion and research. This may be achieved by involving academics from universities. The Darul Ulooms could facilitate continuous development programmes for its teachers. These could be formal and informal during which teachers master their subjects, as well familiarise themselves with teaching methodologies and approaches. It could possibly include some vocational skills, which ensure that the graduates acquire some skills, which would assist them in attaining financial independence.

Focusing on the indigenous community is important. The continuous focus on the Urdu language and an Indian Islamic legacy is a potential problem. The Darul Ulooms need to move beyond the followers of Asian descent and address the needs of the local black community (Reetz 2016:100).

\section{An analysis of the current curriculum within the Darul Ulooms with some specific curriculum reforms}

It is essential to understand the current curriculum before presenting any recommendations. The South African Darul Ulooms have steered away from the Deoband course that is taught over 8 years. They offer a 6- or 7-year course. At one stage, the Deoband syllabus included 28 subjects and almost 
100 books. In 1995, an Urdu or Persian syllabus was introduced and an extensive 8-year Arabic programme (Sikand 2005:97). The Darul Ulooms in South Africa have introduced a 1-year bridging course or preparatory course, which is aimed at students who have no prior knowledge of the recitation of the Quran in Arabic, Urdu and other essentials.

From the second year, the students are introduced into Islamic Jurisprudence (figh) of the Hanafi School beginning with a book entitled Nur al-Idah by Al-Shurunbulali (d. 1658) until the sixth year culminating in the teaching of al-Hidayah by Al-Marghaynani (d. 1782).

Also in the second year, some Hadith and the translation of the meanings of the Quran from Arabic into English are taught along with Arabic grammar, etymology, syntax and literature. Most of these are taught through the Urdu medium. Some basic Persian and some texts on the rules regarding the correct recitation of the Quran (tajwid) are also taught.

The third year is a continuation of the subjects in the second year with the introduction of some exegesis of the Quran (tafsir) and the biography of the Prophet Muhammad.

Subjects, such as tafsir, Arabic literature, syntax and tajwid, continue in the fourth year, with the addition of the laws of Islamic Inheritance and the Principles of Islamic Jurisprudence, which is based on the book Usul al-Shashi, which is difficult for a beginner.

In the fifth year, tajwid and tafsir continue along with the Principles of Islamic Jurisprudence with focus on a text known as Nur al-Anwar by Mulla Jiyun (d. 1715). The new subjects are rhetoric, Islamic theology (aqidah), the Principles of tafsir and some of the rules on the modes of recitation of the Quran.

In the sixth year, the students study a work on tafsir known as al-Jalalayn, a Hadith work known as al-Mishkat, and they are introduced into the principles and terminology of Hadith.

The final year is dedicated to a study of the six canonical books of Hadith, al-Muwatta and Sharh Ma'ani al-Athar (Darul Uloom Zakariyya n.d.).

In comparison, the curriculum at Darul Uloom Deoband is similar with a few additional subjects because of the lengthier duration of the course (Darul Uloom Deoband n.d.).

A comparison of the Darul Ulooms mentioned above reveals that the overall structure of the curriculum and the subjects is the same. The two South African institutions have less content in some subjects because of the 6-year course. The primary focus is on teaching the Hanafi School with an emphasis on Al-Hidayah, which deals with debates within a specific figh school. The different commentaries written on Al-Hidayah kept the scholars engaged and also ensured that the respective schools' extrapolation of laws to new situations would always be of the highest quality. Al-Hidayah covers sections on worship, marriage, divorce, finance, business and inheritance (Karamali 2017:24-25). It provides few guidelines on government and judicial matters, which is understandable because governments and the style of governing change.

These Darul Ulooms have not included in their curriculum any study of the objectives of the Shariah, any formal study of Sufism, the Islamic approach to politics, anthropology, ethics and reasons for disagreement amongst the scholars, research methodology and contemporary issues relating to finance and medicine. The study of Sufism is interesting, because the institutions fail to manage the interrelationship between the academic programme and Sufism. The question is, are they promoting a madrasa and Sufi hospice (zawiyah) or a zawiyah within a madrasa? (Harris \& Reinfield 2006:73). Often, because of the senior teacher's affiliation to a Sufi order, the students are encouraged to follow suit, and in the process the academic standards are sacrificed.

The introduction of classical figh texts that deal with comparative figh such as Badai al-Sanai by Al-Kasani (d. 1191) and Fath al-Qadir by Ibn al-Hummam (d. 1457), is essential. These books within the Hanafi School engage in academic discussions within a single school and other schools. This is performed with reference to the principles of Islamic Jurisprudence. These books provide insights into the reasoning and application of the principles of Islamic Jurisprudence in deducing Islamic legal verdicts. It develops the juristic acumen and provides insight as to how different jurists used proofs and evidences to substantiate their legal verdicts. The inclusion of 'Ila al-Sunan by Zafar Uthmani (d. 1974) will help to establish the link between the juristic rulings and the evidences from the statements of the Prophet Muhammad and his companions. Time may only allow for the teaching of the two introductory volumes and selected Hadith (Hefner \& Zaman 2007:64).

This may be supplemented with a comparative study of the 'principles of Islamic Jurisprudence'. The Hanafi scholars adopted an inductive approach through which they identified juristic theories and principles from juristic and legal responses. The Shafi'i scholars adopted a deductive approach that involved deducing the principles from the sources. This approach developed a framework for extracting rulings from the texts (Ramadan 2009:44-58). If students are exposed to both methodologies, they will graduate with understanding and appreciation of the processes, approaches and methodologies used by the jurists and enable them to effectively extract verdicts for new issues when they arise. This will provide useful insights into the reasons and the ethics of disagreement amongst the scholars.

The Nizami and Deobandi curriculum allocated much time to the teaching of logic and dialectics, which were used extensively in theology (kalam). There is a need for addressing modern ideological trends. Historically, the Darul Ulooms taught students how to refute and present rebuttals of other ideologies, 
which often breeds dissension. The principles of Islamic Jurisprudence, which incorporates (kalam) demonstrates how the accepted sources and evidences in Islam could be used to infer legal rulings. Thus, the combination of logic, kalam and usul al-figh will enable the graduates to provide rulings and also rationally demonstrate how a ruling was, indeed, the command of Allah.

The study of the principles of Islamic Jurisprudence includes a complex topic that deals with analogy (qiyas), particularly on the legal causes ('illat), and how it is determined and then applied in order to extrapolate a new ruling. The Darul Ulooms must reconsider the approach to teaching these subjects (Karamali 2017:6-21). It may be more effective to teach two books on the subject, one modern text and one classical text along with examples and practical application by students. The book Shifa al-Ghalil by Al-Ghazali specifically deals with legal causes.

The present curriculum places a huge amount of emphasis on the study of Hadith. The student is exposed to thousands of narrations during the course. The study of Hadith generally involves two components, namely: (1) Learning the meanings of the Hadith. (2) Learning about Hadith criticism and the narrators (Karamali 2017:18). Instead of completing some books like Sunan al-Nisai and Sunan Ibn Majah, the student could be exposed to the methodologies employed by the compilers of Hadith in documenting these narrations. This will develop the students thinking ability and will broaden his perspective and understanding because he will be exposed to a range of different approaches and interpretations of the Hadith. In this way the student will develop the ability to apply his understanding of the Hadith to various current situations.

Some Darul Ulooms teach students the meanings of the words and verses of the Quran in the formative years. In the later years, Tafsir al-Jalalayn and Al-Baydawi is taught. Time must be allocated to familiarise the students with other works on Tafsir.

In South Africa a more structured programme dedicated to teaching research, public speaking and how to present Islam to people of other faiths must be included. This must be performed in English because graduates will eventually have to present their knowledge to the public. The teaching of Arabic must be emphasised because it will provide a student with a solid foundation and greater confidence in his or her overall ability to comprehend and navigate around Arabic books that were not formerly taught during the course, which is an important lesson from the mahdarah (Karamali 2017:4,18).

\section{Some themes from Al-Mawwaq's book that will be useful in enhancing and reforming the Darul Uloom curriculum}

Al-Mawwaq addressed some issues that may be used to reform and enhance the Darul Uloom curriculum. He excelled in figh, particularly in the Maliki School, as is evident from his detailed commentary on Mukhtasar al-Khalil and a book that contains his legal verdicts (fatwa). He certainly interacted with people of other faiths who resided in the city, whilst serving as an imam and juris consult (mufti). Therefore, his perspectives and understanding are very important, especially as his book appears to be a combination of the objectives (maqasid) of the Shariah that is manifested in Figh and Sufism. By merging these two subjects, he offers very important guidelines for the juris consult in his capacity as a scholar and also guidelines that will develop and refine the scholars' character and personality so that he is able to understand different opinions.

Al-Mawwaq based his book on verse: $32-33$ of Surah Fatir in the Quran. He discussed this verse by referring to nine stations or categories. Some of the topics in his book that are relevant to enhancing and reforming the Darul Uloom curriculum are as follows:

\section{Concessions in Islamic Jurisprudence}

This refers to a valid excuse that warrants the abandoning of the original Islamic ruling in favour of concession. The acceptable excuses include severe illness that is life-threatening, dire necessity and travel (Al-Zuhayli 1993:28) However, Al-Mawwaq is referring to the situation where there are multiple views amongst the jurists on a specific matter. Thus, when a jurist is approached with a question, he ought to direct the questioner to the concession or the easier of these opinions. This can only be carried out if and when the students are exposed to these different views along with a sound understanding of the application of the objectives of the Shariah.

\section{Innovation (bid'ah) in Islam}

The curriculum must allow for a detailed study of the concept of 'innovation' within Islam. The understanding must be in accordance with the majority of scholars, which is less restrictive and will allow for more robust discussion and tolerance of different views.

\section{Jihad and the oppressive government}

The topic of jihad, the government and the Islamic understanding of citizenship are necessary additions to the curriculum. Because of the absence of these topics, the graduate has very little or no sound understanding of how to navigate through the changing political climate globally. Hence, the Darul Ulooms have often been accused of being breeding grounds for extremist ideology. These accusations are justified because of the madrasas antiquated ways and its stubborn resistance to modernisation and the role played by some affiliated institutions in countries, such as Pakistan (Noor et al. 2008:11-14). The reality is that these institutions are not 'terrorist factories' but pious reformist institutions that have propelled Muslim scholarship across the globe (Ingram 2018:30). In 2006, Peter Bergen and Swati Pandey researched the educational backgrounds of 79 terrorists behind attacks against westerners, and they found that the majority were 
western college educated and only nine attended madrasas. Often, the example of the Taliban in Afghanistan is cited, who when they assumed power banned female education and were responsible for an extremist ideology.

(Vestenskov 2018:101). The Darul Ulooms that are aligned to the methodology of Deoband cannot be blamed because these Taliban-supported institutions had often combined the Deobandi thought with radical Salafi ${ }^{1}$ thinking by promoting the works and views of Muhammad ibn Abdul Wahhab (d. 1792) and Ibn Taymiyah (d.1328) (Singer 2001:3-5; Vestenskov 2018:103, 112).

The Darul Ulooms can introduce the subject of Islamic politics and contemporary issues that include governance. This will enable the scholar to navigate through the changing political climate globally, and then perhaps the emergence of extremist groups, such as ISIS and Boko Haram, could be avoided. There are books by traditional scholars like alJuwayni (d. 1085), and in recent times, Shaykh Abdul Hayy al-Kettani (d. 1963), which deal with the state, the Caliph, political science and international relations.

This will allow the Muslim to make meaningful contributions to the country and thereby to be good citizens. The Al-Azhar University in Cairo held a seminar on the Islamic perspective and understanding of citizenship (figh al-muwatanah) in 2019. These studies will be useful if studied and adapted to the South African context in a post-apartheid era. This is a topic that is an extension of the discussion on politics and Muslim involvement that ought to be included in the Darul Uloom curriculum.

Once the student understands the role of the state and the citizens' rights and responsibilities and the principles of enjoining good and forbidding evil, which have been elucidated by Al-Mawwaq, he will be better equipped to deal with a wide range of issues. This must be supplemented by the works of contemporary Muslim scholars, such as Muhammad Sa'id Ramadan al-Buti, Yusuf al-Qaradawi and Ali Jumuah. As Al-Mawwaq discusses aspects of figh and Sufism, it is necessary that the understanding of jihad by Sufi is included in this discourse.

\section{The consideration for norms and habits}

Muslims are travelling across the globe for various reasons, and there are Muslims who have made South Africa their home; however, they have their roots in other parts of the world. These people may follow one of the other schools of Islamic Jurisprudence, and definitely have different cultures and norms. The principles of Islamic Jurisprudence take these norms into consideration. Thus, the jurists have stated, ' $[t]$ he norm should be considered in a legal ruling' (Al-Nadwi 1991:256).

\footnotetext{
1.Salafi derived from salaf, which refers to the pious predecessors, is a name given to a reform movement at the turn of the 20 th century. It emphasised a return to 'pure' a reform movement at the turn of the 20th century. It emphasised a return to 'pure' Islamic doctrine with strict adherence to the Quran and the Sunnah, and denounced the unquestioning imitation. It is often used as a synonym for the Wahhabi movement. See http://www.oxfordislamicstudies.com/article/opr/t125/e2072.
}

The curriculum must dedicate more time to understanding this principle along with its application, whilst being mindful of the Hadith warning against emulating a nation (Al-Sijistani 1969:214). This is essential to dispel the perception that Islam is an Arab, Malay or an Indian religion.

\section{Knowledge and disagreement amongst the scholars}

The curriculum must expose its students to a variety of different scholars and written works of the past scholars from places, such as Andalus and the desert of Mauritania, and contemporary scholars. This must be carried out with due consideration and dedication to teaching the 'Causes of Disagreement amongst Scholars' and the 'Ethics of Disagreement'.

\section{Sufism}

Al-Mawwaq dedicates much of his discussion to important issues related to the spiritual development of the individual and its objectives. The Darul Uloom must teach Sufism with its etiquette and not simply suffice with a few rituals or what may seem as a cult-like adherence to a spiritual guide. The knowledge of Sufism along with the practical acts of devotion and worship will produce a spiritually charged graduate.

\section{Conclusion}

It is evident from the study that the Muslims were motivated from the very beginning to acquire knowledge and disseminate it. This dedication to knowledge transformed Spain into an intellectual hub responsible for major achievements, and it transformed the somewhat unknown deserts of Mauritania into a land that prides itself in its mastery of the Arabic language, an amazing tradition of memorisation and thousands of manuscripts. Ultimately, it is this knowledge, if reformed along with sound morals and values, will most certainly transform the South African Muslim society.

An effective educational system combining the old and the new will preserve Islamic values and enable Muslims to be self-sufficient and allow them to flourish in the modern world. A cosmopolitan approach to blended learning will solidify the foundations of Muslim identity (Moosa 2015:243). If the suggested changes are made as indicated in AlMawwaq's book, along with some innovation in pedagogy, adjustments to the administration and governance of these institutions, and effective financial management, then these institutions will be beacons of hope for South Africa.

\section{Acknowledgements Competing interests}

The authors declare that they have no financial or personal relationships that may have inappropriately influenced them in writing this article.

\section{Authors' contributions}

S.A. conceptualised and visualised the crux of the article and wrote the first draft of the manuscript. M.S. supervised the 
draft, and developed the methodology and formal analysis. Both authors reviewed and edited the final draft.

\section{Ethical considerations}

This article followed all ethical standards for research without any direct contact with human or animal subjects.

\section{Funding information}

This research work received no specific grant from any funding agency in the public, commercial or not-for-profit sectors.

\section{Data availability}

Data sharing is not applicable to this article as no new data were created or analysed in this study.

\section{Disclaimer}

The views and opinions expressed in this article are those of the authors and do not necessarily reflect the official policy or position of any affiliated agency of the authors.

\section{References}

Al-Kawthari, M.Z., 1968, Fiqh ahl al-Iraq wa Hadithuhum, Idarat Nashr al-Kutub, Karachi.

Al-Mawwaq, M.Y., 2002, Sanan al-Muhtadin fi Maqamat al-Din, Mu'assasah al-shaykh marbiyah, Sale.

Al-Nadwi, A.A., 1991, al-Qawa'id al-Fiqhiyah, Dar al-Qalam, Damascus.

Al-Sijistani, A.D., 1969, Sunan Abi Dawud, Dar al-Hadith.

Al-Zirikli, K., 1998, al-'Alam, Dar al-Ilm li al-Malayin, Beirut.

Al-Zuhayli, W., 1993, al-Rukhas al-Shariyah: Ahkamuha wa Dawabituha, Dar al-Khayr, Beirut.

Bruckner, M. \& Kandzin, P.-T., 2001, OMAR: An Oriental database for oriental manuscripts, viewed 20 March 2019, from http://citeseerx.ist.psu.edu/viewdoc/ download?doi=10.1.1.29.3690\&rep=rep1\&type=pdf.

Da Costa, Y. \& Davids, A., 1994, Pages from Cape Muslim history, Naqshbandi Muhammadi, Cape Town.

Darul Uloom Deoband, n.d., Homepage, viewed 03 May 2019, from viewed from www.darululoom-deoband.com.

Darul Uloom Zakariyya, n.d., Courses, viewed 03 May 2019, from https://duz.co.za/ index.php/general-information/courses.

Harris, J-P. \& Reinfield, H. (ed.), 2006, Islamic education, diversity and national identity. Dini madaris Post 9/11, Sage, London.

Hefner, R.W. \& Zaman, M.Q., 2007, Schooling Islam: The culture and politics of modern Muslim education, Princeton University Press, Princeton, NJ.
Hiskett, M., 1984, The development of Islam in West Africa, Longman, New York, NY. Ingram, B.D., 2011, Deobandis abroad, UMI Dissertation Publishing, Chapel Hill, NC. Ingram, B.D., 2018, Revival from below: The Deoband movement and global Islam, University of California Press, Berkeley, CA.

Karamali, H., 2017, The Madrasa curriculum, Kalam Research \& Media, Abu Dhabi.

Kratli, G., 2004, The book and the sand: Restoring and preserving the ancient desert libraries of Mauritania, viewed 11 April 2019, from www.worlib.org/vol4no1/ kratli.

Lovejoy, P., 2009, Islamic scholarship and understanding history in West Africa before 1800, viewed 16 April 2019, from https://www.academia.edu/3651413/Islamic Scholarship_and_Understanding_History_in_West_Africa.

Mazhari, W., 2017, The Quran and acceptance of other religions, viewed 11 April 2020, from http://warismazhari.blogspot.com/.

Metcalf, B., 1978, 'The Madrasa at Deoband: A model for religious education in modern India', Modern Asian Studies 12(1), 111-134. http://www.jstor.org/ stable/311825

Miller, K., 2000, 'Muslim minorities and the obligation to emigrate to Islamic territory. Two Fatwa's from the 15th century', Islamic Law Society 7(2), 256-288. https:// doi.org/10.1163/156851900507643

Moosa, E., 2015, What is a Madrasa?, Edinburgh University Press, Edinburgh.

Noor, F.A., Sikand, Y. \& Bruinessen, M.V., 2008, The Madrasah in Asia: Political Activism and transnational linkages, Amsterdam University Press, Amsterdam.

Oxford Islamic Studies Online, n.d., Salafi, viewed 14 June 2019, from http://www. oxfordislamicstudies.com/article/opr/t125/e2072.

Qasimi, M.K., 2016, Influence of Deoband school of thought in South Africa, Research Paper, University of KwaZulu-Natal, Durban.

Ramadan, T., 2009, Radical reform: Islamic ethics and literature, Oxford University Press, New York, NY.

Reetz, D., 2016, The Tablighi Madrasas in Lenasia and Azaadville: Local players in the global Islamic field, viewed 07 May 2019, from https://www.academia. edu/5766178/The_Tablighi_Madrasas_in_Lenasia_and_Azaadville_Local_ Players_in_the_Global_Islamic_Field_?auto=download.

Rizvi, M., 1980, History of Darul Uloom Deoband, City Mill Compound, Ahmedabad.

Saalim, M.A., 2004, al-hudur al-Andalusi fi al-thaqafah al-mauritania, University of Nouakchott, Nouakchott.

Sayed, M.K., 2010, 'Shifting of the world of South African Madrasah's 1973-2008', MA thesis, Department of Social Science, University of Cape Town.

Shaikh, A., 1994, 'Muslim private schools in SA: Present and future', MA thesis, University of Durban-Westville, Durban.

Sikand, Y., 2005, Bastions of the believers: Madrasas and Islamic education, Penguin Books, New Delhi.

Sikand, Y., 2008, Madrasa reforms: Indian Muslim voices, Vikas Adhyayan Kendra, Mumbai.

Singer, P.W., 2001, Ensuring a system of education not Jihad, Analysis Paper 14, viewed 18 Febraury 2020, from https://www.brookings.edu/research/pakistansmadrassahs-ensuring-a-system-of-education-not-jihad/?amp.

Tayob, A., Niehaus, I. \& Weisse, W., 2011, Muslim schools and education in Europe and South Africa, Waxmann Verlag, Berlin.

Vestenskov, D. (ed.), 2018, The role of Madrasas, Royal Danish College, Copenhagen.

Wald Maqam, A.S., 2014, al-Manhaj al-Tarbawy li al-mahdarah al-Mauritania, viewed 20 March 2019, from http://echourouqmedia.net/?q=node/407.

Wald Mayarah, A., 2013, Ishamat al-Shanaqitah 'abr al-Tarikh, viewed 12 September 2018, from www.elmouragheb.com/826. 